\title{
Dero (Allodero) lutzi Michaelsen, 1926 (Oligochaeta: Naididae) associated with Scinax fuscovarius (Lutz, 1925) (Anura: Hylidae) from Semi-deciduous Atlantic Rain Forest, southern Brazil
}

\author{
Oda, FH. ${ }^{a, c *}$, Petsch, DK. ${ }^{b, c}$, Ragonha, FH..$^{b, c}$, Batista, VG. ${ }^{c}$, \\ Takeda, AM..$^{b, c}$ and Takemoto, RM..$^{a, c}$ \\ ${ }^{a}$ Núcleo de Pesquisas em Limnologia, Ictiologia e Aqüicultura - Nupélia, Laboratório de Ictioparasitologia, Universidade \\ Estadual de Maringá - UEM, Bloco G-90, Av. Colombo, 5790, CEP 87020-900, Maringá, PR, Brazil

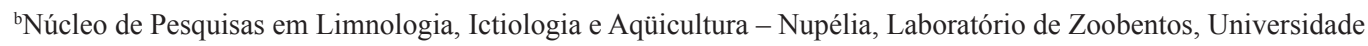 \\ Estadual de Maringá - UEM, Bloco H-90, Av. Colombo, 5790, CEP 87020-900, Maringá, PR, Brazil \\ 'Programa de Pós-Graduação em Ecologia de Ambientes Aquáticos Continentais - PEA, Universidade \\ Estadual de Maringá - UEM, Bloco G-90, Av. Colombo, 5790, CEP 87020-900, Maringá, PR, Brazil \\ *e-mail: fabricio_oda@hotmail.com
}

Received: May 10, 2013 - Accepted: November 6, 2013 - Distributed: March 31, 2015

(With 1 figure)

\begin{abstract}
Amphibians are hosts for a wide variety of ecto- and endoparasites, such as protozoans and parasitic worms. Naididae is a family of Oligochaeta whose species live on a wide range of substrates, including mollusks, aquatic macrophytes, sponges, mosses, liverworts, and filamentous algae. However, some species are known as endoparasitic from vertebrates, such as Dero (Allodero) lutzi, which is parasitic of the urinary tracts of frogs, but also have a free-living stage. Specimens in the parasitic stage lack dorsal setae, branchial fossa, and gills. Here we report the occurrence of D. (A.) lutzi associated with anuran Scinax fuscovarius from Semi-deciduous Atlantic Rain Forest in southern Brazil. The study took place at the Caiuá Ecological Station, Diamante do Norte, Paraná, southern Brazil. Seven specimens of $S$. fuscovarius were examined for parasites but only one was infected. Parasites occurred in ureters and urinary bladder. Previous records of this D. (A.) lutzi include the Brazilian States of Santa Catarina, São Paulo, Rio de Janeiro, and Minas Gerais, as well as Cuba and North America. This is a new locality record for this species in Brazil. Reports of Dero (Allodero) lutzi are rare, due to difficulty of observation, and such events are restricted only the fortuitous cases. It is important to emphasize the necessity of future studies, which are fundamental to the understanding of biological and ecological aspects of this species.
\end{abstract}

Keywords: anuran, Hylidae, endoparasite, urinary tract, Annelida.

\section{Dero (Allodero) lutzi Michaelsen, 1926 (Oligochaeta: Naididae) associado com Scinax fuscovarius (Lutz, 1925) (Anura: Hylidae) na Floresta Estacional Semidecidual, Sul do Brasil}

\begin{abstract}
Resumo
Anfíbios são hospedeiros para uma grande variedade de ecto- e endoparasitos, tais como os protozoários e vermes parasitos. Naididae é uma família de Oligochaeta cujas espécies vivem em uma ampla variedade de substratos, incluindo moluscos, macrófitas aquáticas, esponjas, musgos, e algas hepáticas e filamentosas. No entanto, algumas espécies são conhecidas como endoparasitos de vertebrados, como Dero (Allodero) lutzi, o qual é um parasito do trato urinário de anfíbios, mas que também possui uma fase de vida livre. Espécimes no estágio parasitário não possuem cerdas dorsais, fossa branquial, e brânquias. Relatamos a ocorrência de $D$. (A.) lutzi associado ao anuro Scinax fuscovarius na Floresta Estacional Semidecidual no Sul do Brasil. O estudo foi realizado na Estação Ecológica do Caiuá, Diamante do Norte, Paraná, Sul do Brasil. Sete espécimes de S. fuscovarius foram examinados para parasitos, mas apenas um estava infectado. Os parasitos ocorreram nos ureteres e bexiga urinária. Registros anteriores de $D$. (A.) lutzi incluem os estados brasileiros de Santa Catarina, São Paulo, Rio de Janeiro e Minas Gerais, bem como Cuba e América do Norte. Este é o registro de uma nova localidade para esta espécie no Brasil. Registros de Dero (Allodero) lutzi são raros, devido à dificuldade de observação, e tais eventos são restritos apenas a casos fortuitos. É importante ressaltar a necessidade de futuros estudos, que são fundamentais para a compreensão de aspectos biológicos e ecológicos desta espécie.
\end{abstract}

Palavras-chave: anuro, Hylidae, endoparasitas, trato urinário, Annelida. 


\section{Introduction}

Amphibians are hosts for a wide variety of ecto- and endoparasites. Internal parasites of amphibians include protozoans, as well as a variety of parasitic worms (see Wells, 2007). The latter include tapeworms (Cestoda) (Melo et al., 2011), intestinal round worms (Acanthocephala) (Salgado-Maldonado and Caspeta-Mandujano, 2010), tongue worms (Pentastomida) (Christoffersen and De Assis, 2013), nematodes that infect the lungs and visceral organs (Van Sluys et al., 2006), and monogenean and digenean helminths that infect the lungs, muscles, bladder, and digestive organs (Hamann and González, 2009; Santos and Amato, 2012).

Scinax fuscovarius are medium-sized tree frogs widely distributed in southeastern Brazil, northern Argentina, Paraguay, Bolivia, and Uruguay (Haddad et al., 2008; Almeida-Gomes et al., 2010; Frost, 2013). During the day, it shelters in burrows, crevices, trees, soil, and human construction (Araujo et al., 2009).

Species of the family Naididae (Oligochaeta) can live on a considerable range of substrates, including mollusks (Gorni and Alves, 2006), aquatic macrophytes (Mastrantuono, 1986), sponges (Righi, 1984), mosses, liverworts (Vlckvá et al., 2002), and filamentous algae (Armendáriz, 2000). However, some species are known as endoparasitic from vertebrates (see Harman, 1971).

The subgenus Allodero was erected by Sperber (1948) within the genus Dero (Naididae, Oligochaeta) for parasitic or symbiotic species known from Asia, Africa, and South America (Harman, 1971). Allodero, Aulophorus and Dero are considered subgenera of Dero by some authors (e.g. Milligan, 1997; Kathman and Brikhurst, 1998; Wetzel et al., 2012). However, Cekanovskaya (1962) and Liang (1964) considered Dero and Aulophorus as separate genera, while the latter author also separated Allodero at the generic level. More recently, Aulophorus was listed as a full genus (Timm, 1999). However, we prefer to refer individuals from this study as Dero (Allodero) lutzi until a revision of the subgenus Allodero is effectively conducted.

The subgenus Allodero consists only of one species, D. (Allodero) lutzi Michaelsen, 1926. Dero (Allodero) lutzi is an endoparasitic of the urinary tracts of frogs of the genus Hyla (Maldonado and Oliveira, 1982; Rodrigues and Maldonado Junior, 1982), which also have a freeliving stage. Specimens in the parasitic stage lack dorsal setae, branchial fossa, and gills, but when cultured in a free-living form, they developed dorsal setae as well as caudal fossa and gills (Harman and Lawler, 1975). Here we report the occurrence of the endoparasitic Oligochaeta, Dero (Allodero) lutzi in the snouted tree frog, Scinax fuscovarius, from Semi-deciduous Atlantic Rain Forest in southern Brazil.

\section{Material and Methods}

This study took place in the Caiuá Ecological Station $\left(22^{\circ} 37^{\prime} \mathrm{S}\right.$ and $52^{\circ} 50^{\prime} \mathrm{W}, 268 \mathrm{~m}$ asl $)$, in the municipality of Diamante do Norte, Paraná, Brazil. The region is inserted in the Semi-deciduous Atlantic Rain Forest. Specimens of Scinax fuscovarius $(\mathrm{n}=7$, mean $\mathrm{SVL}=40.9 \mathrm{~mm}, \pm 3.7 \mathrm{SD}$ and mean body weight $4.5 \mathrm{~g}, \pm 1.4 \mathrm{SD}$ ) were collected in temporary and permanent ponds during visual encounters surveys in February, April, and October 2012. Individuals were taken to the laboratory where they were euthanatized with Lidocaine 5\%. Subsequently, the lungs, digestive tract, urinary tract, muscle, skin, spleen, and liver were examined for parasites. The Oligochaeta were identified in semi permanent slides. All anurans are housed at the zoological collection of the Universidade Federal de Goiás (ZUFG), Goiânia, Goiás, central Brazil (ZUFG 7109-7113, 7190, 7208). Voucher parasite specimens are housed at the Helminthological collection of the Instituto Oswaldo Cruz (CHIOC), Rio de Janeiro, Rio de Janeiro, Brazil (CHIOC 35863). The current nomenclature of anurans follows Faivovich et al. (2005), Lema and Martins (2011), Frost (2013).

\section{Results and Discussion}

Seven specimens of Scinax fuscovarius were examined for parasites. Analyses of the treefrogs demonstrated that one specimen (male, $\mathrm{SVL}=40.75 \mathrm{~mm}$, weight $=4.53 \mathrm{~g}$ ) was infected by Dero (Allodero) lutzi $(\mathrm{n}=14$, mean length $=3.06 \mathrm{~mm}, \pm 0.51 \mathrm{SD}$; Figure 1), which were found in
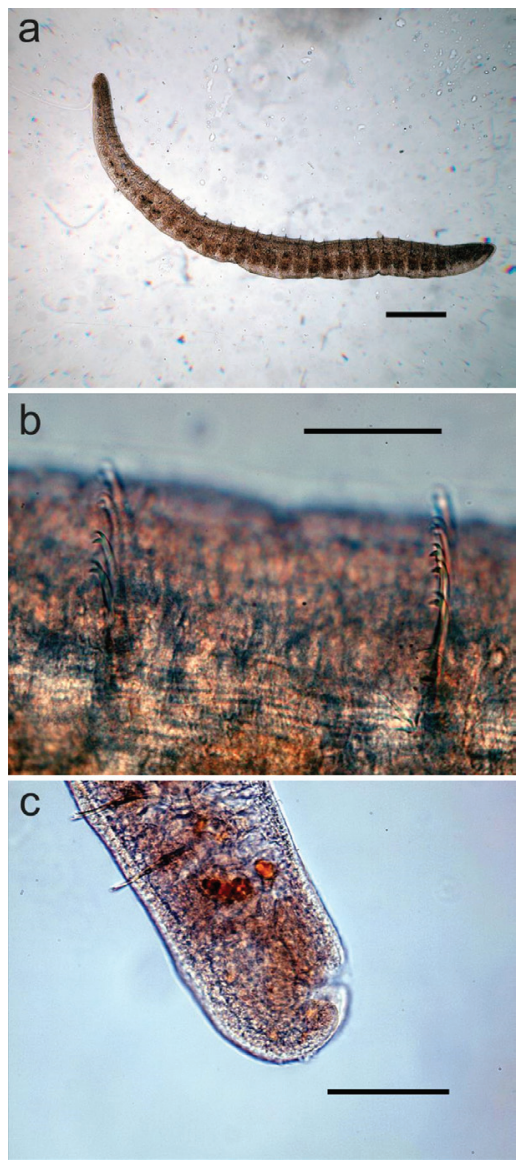

Figure 1. Dero (Allodero) lutzi found in an adult male of Scinax fuscovarius: a) general aspect $(\mathrm{Bar}=500 \mathrm{~mm}) ; \mathrm{b})$ ventral setae $($ Bar $=50 \mathrm{~mm})$; c) rudimentary caudal fossa (Bar $=150 \mathrm{~mm})$. 
ureters and urinary bladder. These oligochaetes are freeliving animals (Rodrigues and Maldonado Junior, 1982), which are adapting to parasitism, since the ecological conditions of the bladder and ureters of amphibians resemble those of the external liquid environment used by the frogs. However, the exact route of transmission of naids to frogs is unknown, but previous studies suggest that frogs are infected during the larval stage (Harman and Lawler, 1975).

Only Dero is known to use frogs for transport and as hosts among the Brazilian freshwater genera of naidids (Righi, 1984; Lopez et al., 1999). As example, Dero superterrenus Michaelsen, 1912 are free-living inhabitants of tank bromeliads and tree holes and can use amphibians to disperse (Lopez et al., 1999). Laboratory experiments support the hypothesis that the phoretic behaviour presented by $D$. superterrenus is stimulated by chemical substances released by amphibian skins (Lopez et al., 2005). Lopez et al. (2005) suggest that if $D$. (A.) lutzi use the same chemical substances used by $D$. superterrenus to find their amphibian vectors, it will strengthen the hypothesis that parasitic and phoretic behaviours using frogs are evolutionarily linked in the annelid Dero group. Thereby, D. superterrenus and $D$. (A.) lutzi might have shared a close common ancestor with parasitic or phoretic behavior (Lopez et al., 2005).

Reports on Dero (A.) lutzi are scarce and restricted to a few anuran species. The first record was made on Trachycephalus cf. typhonius, Hypsiboas albomarginatus, Scinax gr. ruber and Dendropsophus minutus (Lutz, 1926). Lutz (1927) found the species in Hypsiboas faber (Brazil) and Osteopilus septentrionalis from Cuba. Righi (1972) also found D. (A.) lutzi in Scinax strigilatus and considered Schmardaella hylae Goodchild 1951, parasite of Hyla squirella, a synonym of $D$. (A.) lutzi. More recently, oligochaetes were expelled along with eggs of Trachycephalus mesophaeus during oviposition (Prado et al., 2003). The current taxonomy of hosts is presented in Table 1. The reported of $S$. fuscovarius as host of $D$. (A.) lutzi represents a new host record for this Oligochaeta endoparasite.

Previous records of Dero (A.) lutzi include the Brazilian States of Santa Catarina, São Paulo, Rio de Janeiro, and

Table 1. Checklist of anuran species host of Dero (Allodero) lutzi.

\begin{tabular}{cccc}
\hline Host & Locality / Country & $\begin{array}{c}\text { Current taxonomy } \\
\text { (Host) }\end{array}$ & Source \\
\hline
\end{tabular}

BUFONIDAE

Bufo crucifer

Nova Iguaçú, RJ (BRA)

Rhinella ornata

Rodrigues and Maldonado Junior (1982)

HYLIDAE

Hyla misera

Rio de Janeiro, RJ (BRA)

Maracay (VEN)

Hyla bilineata

São Paulo, SP (BRA)

Hyla albomarginata

Rio de Janeiro, RJ (BRA)

Hyla faber

(BRA)

Diamante do Norte, PR (BRA)

Hyla strigilata

Lauro Müller, SC (BRA)

Hyla rubra

Belo Horizonte, MG (BRA)

São Paulo, SP (BRA)

Hyla venulosa

Rio de Janeiro, RJ (BRA)

Phrynohyas mesophaea

Ubatuba, SP (BRA)

Maracay (VEN)

Hyla septentrionalis

(CUB)

Hyla squirella

Dade County, Florida (USA)
Dendropsophus cf. meridianus

Dendropsophus microcephalus

Dendropsophus minutus

Hypsiboas albomarginatus

Hypsiboas faber

Scinax fuscovarius ${ }^{\mathrm{b}}$

Scinax gr. catharinae

Scinax gr. ruber

Trachycephalus cf. typhonius

Trachycephalus

mesophaeus

Osteopilus septentrionalis

Hyla squirella
Rodrigues and Maldonado Junior (1982)

Rodrigues and Maldonado Junior (1982)

Rodrigues and Maldonado Junior (1982)

Rodrigues and Maldonado Junior (1982)

Rodrigues and Maldonado Junior (1982)

Rodrigues and Maldonado Junior (1982)

Rodrigues and Maldonado Junior (1982)

Prado et al. (2003)

Rodrigues and Maldonado Junior (1982)

Rodrigues and Maldonado Junior (1982)

a BRA, Brazil: MG, Minas Gerais; PR, Paraná; RJ, Rio de Janeiro; SC, Santa Catarina; SP, São Paulo; CUB, Cuba; VEN, Venezuela; USA, United States of America; ${ }^{\mathrm{b}}$ This study; ${ }^{\mathrm{c}}$ name unknown (possible confusion with Hyla bivittata). 
Minas Gerais, as well as Cuba and North America (Righi, 1984; Christoffersen, 2007). Therefore, our record in Paraná represents a new locality for $D$. (A.) lutzi.

Reports of Dero (A.) lutzi are rare, due to difficulty of observation. Such events are restricted to fortuitous cases. In this context, it is important to emphasize the need for future studies to the understanding of biological and ecological aspects of $D$. (A.) lutzi.

\section{Acknowledgements}

We are grateful to José Perez Pombal Jr. for the identification of the anuran species, to Valdir, José Cândido, Valdenir, Celso, Fagner, Fábio, and Rodrigo for field assistance. Ângelo A. Agostinho and Rosimeire R. Antônio provided microscope with digital camera. Diogo B. Provete reviewed the English language. The Caiuá Ecological Station and Nupélia provided logistical support during fieldwork. The CAPES/PROEX provided financial support. FHO, DKP, FHR, VGB received Master and $\mathrm{PhD}$ fellowships from CAPES. RMT is a CNPq fellow (process \# 305829/2010-6).

\section{References}

ALMEIDA-GOMES, M., ALMEIDA-SANTOS, M., GOYANNESARAÚJO, P., BORGES-JÚNIOR, VNT., VRCIBRADIC, D., SIQUEIRA, CC., ARIANI, CV., DIAS, AS., SOUZA, VV., PINTO, RR., VAN SLUYS, M. and ROCHA, CFD., 2010. Anurofauna of an Atlantic Rainforest fragment and its surroundings in Northern Rio de Janeiro State, Brazil. Brazilian journal of biology $=$ Revista brasileira de biologia, vol. 70, no. 3, p. 871-877. http:// dx.doi.org/10.1590/S1519-69842010000400018. PMid:21085792

ARAUJO, CO., CONDEZ, TH. and SAWAYA, RJS., 2009. Anfíbios Anuros do Parque Estadual das Furnas do Bom Jesus, sudeste do Brasil, e suas relações com outras taxocenoses no Brasil. Biota Neotropica, vol. 9, no. 2, p. 77-98. http://dx.doi. org/10.1590/S1676-06032009000200007.

ARMENDÁRIZ, LC., 2000. Populations dynamics of Stylaria lacustris (Linnaeus, 1767) (Oligochaeta, Naididae) in Los Talas, Argentina. Hydrobiologia, vol. 438, no. 1-3, p. 217-226. http:// dx.doi.org/10.1023/A:1004139622036.

CEKANOVSKAYA, OV., 1962. The aquatic Oligochaeta of the U.S.S.R. Oprediteli po faune SSSR, vol. 78, p. 1-411.

CHRISTOFFERSEN, ML., 2007. A catalogue of aquatic microdrile oligochaetes (Annelida: Clitellata) from South America. Acta Hydrobiologica Sinica, vol. 31, p. 59-86.

CHRISTOFFERSEN, ML. and DE ASSIS, JE., 2013. A systematic monograph of the Recent Pentastomida, with a compilation of their hosts. Zoologische Mededeelingen, vol. 87, no. 1, p. 1-206.

FAIVOVICH, J., HADDAD, CFB., GARCIA, PCA., FROST, DR., CAMPBELL, JA. and WHEELER, WC., 2005. Systematic Review of the Frog Family Hylidae, With Special Reference to Hylinae: Phylogenetic Analysis and Taxonomic Revision. Bulletin of the American Museum of Natural History, vol. 294, no. 1, p. 1-240. http://dx.doi.org/10.1206/0003-0090(2005)294[0001:SR OTFF]2.0.CO;2.

FROST, DR., 2013. Amphibian Species of the World 6.0, an Online Reference. New York: American Museum of Natural
History. Available from: <http://research.amnh.org/herpetology/ amphibia/index.html>. Access in: 16 Jan. 2013.

GORNI, GR. and ALVES, RG., 2006. Naididae (Annelida, Oligochaeta) associated with Pomacea bridgesii (Reeve) (Gastropoda, Ampullaridae). Revista Brasileira de Zoologia, vol. 23, no. 4, p. 1059-1061. http://dx.doi.org/10.1590/S010181752006000400011 .

HADDAD, CFB., TOLEDO, LF. and PRADO, CPA., 2008. Anfibios da Mata Atlântica: guia dos anfibios anuros da Mata Atlântica. São Paulo: Editora Neotropica. 244 p.

HAMANN, MI. and GONZÁLEZ, CE., 2009. Larval digenetic trematodes in tadpoles of six amphibian species from northeastern Argentina. The Journal of Parasitology, vol. 95, no. 3, p. 623-628. http://dx.doi.org/10.1645/GE-1738.1. PMid:19045934

HARMAN, WJ., 1971. A review of the subgenus Allodero (Oligochaeta: Naididae: Dero) with a description of $D$. (A.) floridana $\mathrm{n}$. sp. from Bufo terrestris. Transactions of the American Microscopical Society, vol. 90, no. 2, p. 225-228. http://dx.doi. org/10.2307/3225029.

HARMAN, WJ. and LAWLER, AR., 1975. Dero (Allodero) hylae, an oligochaete symbiont in hylid frogs in Mississippi. Transactions of the American Microscopical Society, vol. 94, no. 1, p. 38-42. http://dx.doi.org/10.2307/3225530.

KATHMAN, RD. and BRIKHURST, RO., 1998. Guide to the freshwater oligochaetes of North America. Tennessee: Aquatic Resources Center/College Groove. 264 p.

LEMA, T. and MARTINS, LA., 2011. Anfibios do Rio Grande do Sul: Catálogo, Diagnoses, Distribuição, Iconografia. Porto Alegre: EDIPUCRS. 196 p.

LIANG, YL., 1964. Studies on the aquatic Oligochaeta of China, II: On some species of Naididae from Sinkiang with description of a new species Allodero prosetosa. Acta Zoological Sinica, vol. 16 , no. 4, p. 643-652.

LOPEZ, LCS., RODRIGUES, PJFP. and RIOS, RI., 1999. Frogs and snakes as phoretic dispersal agents of bromeliad ostracods (Elpidium) and Annelids (Dero). Biotropica, vol. 31, no. 4, p. 705-708. http://dx.doi.org/10.1111/j.1744-7429.1999.tb00421.x.

LOPEZ, LCS., FILIZOLA, B., DEISS, I. and RIOS, RI., 2005. Phoretic behaviour of bromeliad annelids (Dero) and ostracods (Elpidium) using frogs and lizards as dispersal vectors. Hydrobiologia, vol. 549, no. 1, p. 15-22. http://dx.doi.org/10.1007/ s10750-005-1701-4.

LUTZ, A., 1926. Trematodes et oligochètes observé dans les canauxs excreteurs du rein des batrachiens de l'Amerique meridionale. Compte Rendus des séances de la Société de Biologie, vol. 95, p. 1503-1504.

LUTZ, A., 1927. Sur la Schmardaella lutzi Michaelsen. Compte Rendus des séances de la Société de Biologie, vol. 96, no. 76, p. 485-486.

MALDONADO, AJ. and OLIVEIRA, HRR., 1982. Ocorrência de Dero (Allodero) lutzi (Michaelsen, 1926) em Bufo crucifer Wied, 1821 no Estado do Rio de Janeiro (Oligochaeta, Naididae). Acta Biológica, vol. 23, p. 13-15.

MASTRANTUONO, L., 1986. Community structure of the zoobentos associated with submerged macrophytes in the eutrophic Lake Nemi (Central Italy). The Italian Journal of Zoology, vol. 53 , no. 1 , p. $41-47$ 
MELO, FT., GIESE, EG., FURTADO, AP., SOARES, MJ., GONÇALVES, EC., VALLINOTO, AC. and SANTOS, JN., 2011. Lanfrediella amphicirrus gen. nov. sp. nov. Nematotaeniidae (Cestoda: Cyclophyllidea), a tapeworm parasite of Rhinella marina (Linnaeus, 1758) (Amphibia: Bufonidae). Memorias do Instituto Oswaldo Cruz, vol. 106, no. 6, p. 670-677. http:// dx.doi.org/10.1590/S0074-02762011000600005. PMid:22012220

MILLIGAN, MR., 1997. Identification manual for the aquatic Oligochaeta of Florida, Volume I - Freshwater oligochaetes. Thallahassee: Florida Department of Environmental Protection/ Bureau of Water Resources Protection.

PRADO, G.M., BORGO, J.H., ABRUNHOSA, P.A. and WOGEL, H., 2003. Comportamento reprodutivo e redescrição do girino de Phrynohyas mesophaea (Hensel, 1867) do sudeste do Brasil (Anura, Hylidae). Boletim do Museu Nacional, Nova Série, Zoologia, no. 510, p. 1-11.

RIGHI, G., 1972. Contribuição ao conhecimento dos Oligochaeta brasileiros. Papéis Avulsos de Zoologia, vol. 25, no. 18, p. 149-166.

RIGHI, G., 1984. Manual de identificação de invertebrados límnicos do Brasil. Brasília: Coordenação Editorial/CNPq.

RODRIGUES, HO. and MALDONADO JUNIOR, A., 1982. Ocorrência de Dero (Allodero) lutzi (Michaelsen, 1926) em Bufo crucifer Wied, 1821 no Estado do Rio de Janeiro (Oligochaeta, Naididae). Atas da Sociedade de Biologia do Rio de Janeiro, vol. 23, p. 13-15.

SALGADO-MALDONADO, G. and CASPETA-MANDUJANO, JM., 2010. Lueheia inscripta (Westrumb, 1821) (Acanthocephala: Plagiorhynchidae) in anurans (Leptodactylidae: Bufonidae) from Mexico. Parasite (Paris, France), vol. 17, no. 2, p. 161-165. http://dx.doi.org/10.1051/parasite/2010172161. PMid:20597444
SANTOS, VGT. and AMATO, SB., 2012. Polystoma cuvieri (Monogenea, Polystomatidae) in Physalaemus cuvieri (Anura, Leiuperidae) in southern Brazil. Neotropical Helminthology, vol. 6 , no. 1, p. 1-7.

SPERBER, C., 1948. A taxonomical study of the Naididae. Zoologiska Bidragen från Uppsala, vol. 28, p. 1-296.

TIMM, T., 1999. Distribution of freshwater oligochaetes in the west and east coastal regions of the North Pacific Ocean. Hydrobiologia, vol. 406, p. 67-81. http://dx.doi.org/10.1023/A:1003749519662.

VAN SLUYS, M., SCHITTINI, GM., MARRA, RV., AZEVEDO, ARM., VICENTE, JJ. and VRCIBRADIC, D., 2006. Body size, diet and endoparasites of the microhylid frog Chiasmocleis capixaba in an Atlantic Forest area of southern Bahia state, Brazil. Brazilian journal of biology $=$ Revista brasileira de biologia, vol. 66, no. 1a, p. 167-173. http://dx.doi.org/10.1590/S151969842006000100021. PMid:16680312

VLCKVÁ, S., LINHART, J. and UVÍRA, V., 2002. Permanent ans temporary meiofauna of an aquatic moss Fontinalis antipyretica Hedw. Acta Universitatis Palackianae Olomucensis Facultas Rerum Naturalium, vol. 39-40, p. 131-140.

WELLS, KD., 2007. The ecology and behavior of amphibians. Chicago: The University of Chicago Press. 1148 p. http://dx.doi. org/10.7208/chicago/9780226893334.001.0001.

WETZEL, MJ., KATHAMAN, RD., FENDN, SV. and COATES, KA., 2012. Classification and checklist of the freshwater Oligochaeta occurring in North America North of Mexico. INHS Center for Annelida Resources. Available from: $<$ http://www.inhs.uiuc. edu/ mjwetzel/FWOligoNAChklst.html>. Acces in: 17 Jan. 2013. 